\title{
CORRELATION OF UMBILICAL CORD LENGTH WITH FOETAL AND MATERNAL OUTCOME.
}

B. B. Yadav, Kurdukar. D.V, R. V. Darade, N. A. Mahadar
1. HOD, Department of Obstetrics \& Gynaecology, Government Medical College, Latur.
2. Professor, Unit Head, Department of Obstetrics \& Gynaecology, Grant Medical College, Mumbai.
3. Associate Professor, Unit Head, Department of Obstetrics \& Gynaecology, Government Medical College, Latur.
4. Chief Resident, Department of Obstetrics \& Gynaecology, Government Medical College, Latur.

\section{CORRESPONDING AUTHOR}

Dr. B. B. Yadav

Head of Department,

Government Medical College Latur,

Maharashtra,

E-mail: drshriyadav@yahoo.co.in

Ph: 00919421096113

\begin{abstract}
INTRODUCTION: The cord disposition and length of umbilical cord in the amniotic cavity remain unrecognised till the birth of the baby.Cord complications remain one of the major causes of foetal death.
\end{abstract}

\section{OBJECTIVES: To study}

1. Length of umbilical cord in new-born babies

2. The outcome of pregnancy with abnormal length of umbilical cord

3. The relation between umbilical cord length and cord abnormalities

4. Relation between umbilical cord abnormalities and perinatal outcome

METHODS: This study of 200 cases was carried out in S.R.T.R. Medical College, Ambajogai over a period of 6 months from Jan 2011 to Jun 2011. 100 cases belonged to control group (cord length 50-60 cm). Study group had short cord (i.e. cord length less than $50 \mathrm{~cm}$ ) comprising 20 cases and long cord (i.e. cord length above $60 \mathrm{~cm}$ ) comprising 80 cases. Apgar score at 1 and 5 minutes after birth were recorded. Birth weight and sex of all babies were noted. Number of loops of cord and position noted. Cord loop tight or loose noted (only for LSCS cases).

RESULTS: Maximum numbers of cases were from age group 20-24 years. Parity was not found to affect cord length. Maximum cases (31.25\%) of foetal distress were found in group with cord length more than $60 \mathrm{~cm}$. Significantly low APGAR score at 5 mins noted in long cord group (15\%) than control group. Cord length in control and study group in relation to the sex of the foetus was found to be statistically insignificant. 30 cases from long cord group required caesarean section and most of them for foetal distress. Cord entanglement (88.75\%) was the most common complication in long cord group.

CONCLUSION: Minimum observed cord length in this study was $28 \mathrm{~cm}$ and maximum cord length was $98 \mathrm{~cm}$. There was no relation between maternal age, parity, sex of the foetus with the umbilical cord length. Cord abnormalities were observed in long cord group only. Higher percentage of caesarean section and perinatal mortality was more in long cord cases.

KEY WORDS: Cord length, Cord entanglement, maternal morbidity, foetal mortality. 
INTRODUCTION: The umbilical cord length, its position in amniotic sac and its anomalies are subject to a wide variations and untoward gestational events. Some cord anomalies lead to indisputable cord failure due to compromise of umbilical blood flow to a degree sufficient to prejudice the life or the well-being of the foetus. The cord disposition and length of umbilical cord in the amniotic cavity remain unrecognised till the birth of the baby. It is mostly discovered while conducting delivery or caesarean section. Despite improved antenatal care, safety during surgery and use of modern monitoring such as ultra-sonography, Doppler and intra-partum foetal monitor, cord complications remain one of the major unavoidable causes of foetal death. Various obstetric mishaps have been ascribed to variations in cord length such as failure of descent of presenting part, prolonged labour, uterine inertia, placental abruption, foetal distress and foetal death. These umbilical cord anomalies are often related to foetal presentation, sex and weight of the infant and age and parity of mother. The study was carried out to find out the correlation of umbilical cord length with maternal age, parity and relationship to the sex of the foetus in group of population and its impact on intrapartum complications, mode of deliveries, perinatal and maternal outcome.

MATERIALS AND METHODS: This cross sectional prospective study was carried out in S.R.T.R. Medical College, Ambajogai over a period of 6 months from Jan 2011 to Jun 2011. The study group included both primigravida and multigravida with singleton pregnancies only. Pregnancies complicated by intrauterine foetal death, malpresentations, multiple gestations, congenital malformations of foetus, diabetes, other metabolic abnormalities, preeclampsia, chorioamnionitis, preterm labour were excluded. The maternal and foetal monitoring in labour were done as per partograph. Foetal heart rate was monitored by intermittent auscultation with stethoscope and foetal Doppler. Details of delivery of baby were recorded. Length of the cord in cms, knots of cord- true or false, distance of the knot from placenta and baby in cms, number of loops of cord and its position, tight coils or as loose coils (only during LSCS), any other abnormalities of cord like hamartoma, cyst were noted. Apgar score at 1 and 5 minutes after birth were noted. Birth weight and sex of all babies were noted. Lengths of cords were measured and labeled as long $(>60 \mathrm{~cm})$, short $(<50 \mathrm{~cm})$ or normal $(50-60 \mathrm{~cm})$. The outcomes with long or short cord (study group) were compared with that of normal length of cord (control group). A data check sheet was maintained for each case till completion of delivery.

RESULTS: There were 100 cases each in control group and study group comprising of 20 cases of short cord and 80 cases of long cords (Table I). Maximum numbers of cases were from age group 20-24 years, i.e. 10 cases in short cord group, 46 cases in long cord group and 52 cases in control group (Table III).Parity did not affect cord length (Table IV). The difference of cord length in relation to the sex of the newborn was found to be insignificant (Table V).

Only $26 \%$ of foetuses with long or short cord length manifested foetal heart rate variations (Table VII). Only 1 (5\%) of 20 cases of short cord had bradycardia, while 25 (31.25\%) of 80 cases of long cord had foetal distress. 6 cases of long cord had absent foetal heart beats, 5 were due to cord prolapse and 1 case was due to nuchal cord. Incidence of all cord complications increased as cord length increased, cord entanglement being most common (Table VIII).

Out of 20 cases of short cord, only 1 baby had APGAR 1-4 at 1 minute, which improved after resuscitation. While out of 80 cases of long cord, 12 babies had APGAR score of 1-4 at 1 minute and of that 9 cases improved on resuscitation (Table IX) 
DISCUSSION: The length of the Umbilical cord varies widely from 0 (Browne, 1923) ${ }^{1}$ to $300 \mathrm{~cm}$ (Malpas, 1960) ${ }^{2}$. The average of the Umbilical cord length is usually between $50-60 \mathrm{~cm}$. In present study average cord length was found to be $57.79 \mathrm{~cm}$, which was slightly more than that described by GulatiBatra ${ }^{6}$ in 1991 and shunji, yukiko ${ }^{11}$ in 2012. In this study minimum length of cord was found to be $28 \mathrm{~cm}$ and longest was found to be $98 \mathrm{~cm}$.

In present study as well as in studies by C. W. Walker ${ }^{3}$ (1960), Agboola ${ }^{4}$ (1978) and Adinma $^{7}$ (1990), it was found that there is no correlation of cord length and maternal age.

Except for Sorens and Bekke ${ }^{5}$ (1989), all other studies including C. W. Walker ${ }^{3}$ (1960), Agboola $^{4}$ (1978) and Adinma ${ }^{7}$ (1990) and present one did not find any correlation of parity with the cord length.

Walker and Pye $^{3}$ (1960), Sorens and Bekke 5 (1985) and Gulati and Batra ${ }^{6}$ (1991) found that cord length of male foetuses $(56.4 \mathrm{~cm}, 58.46 \mathrm{~cm}$ and $57.27 \mathrm{~cm}$ respectively) was longer than that of female foetuses $(52 \mathrm{~cm}, 56.9 \mathrm{~cm}$ and $53.94 \mathrm{~cm}$ respectively). In present study though the difference was not statistically significant, male foetuses $(59.99 \mathrm{~cm})$ had marginally longer cord length than female foetuses $(59.4 \mathrm{~cm})$.

Incidence of foetal distress was more common in cases with long cord length $(31.25 \%)$ compared to short cord (5\%) and controls. this was supported by the study of Rayburn ${ }^{8}$ (1981). Rayburn stated that foetal heart rate abnormalities were seen in $87 \%$ of long cord group and $63 \%$ of short cord group. SinnaThuray ${ }^{10}$ (1966) observed that foetal distress was mainly due to nuchal cords (14.65\%), incidence of same was $36.27 \%$ in present study.

In present study, percentage of LSCS was high (37.5\%) with long cord group as compared to control and short cord group. Similar results were seen in study by Mishra and Vijayalaxmi ${ }^{9}$ (1987), which stated rate of LSCS to be $15 \%$ in long cord group and $30 \%$ in short cord group. According to begum, sultana ${ }^{12}$ percentage of LSCS was $13.8 \%$ with long cord group . In present study, this was explained by the high rate of cord complications associated with the long cord, cord entanglement being the most common (88.75\%).

In present study, $15 \%$ of babies were having low APGAR score (1-4) at birth in long cord group while in short cord group it was $5 \%$ similar results were seen in study by Nilesh and mangla shinde. ${ }^{13 .}$

In present study 6 cases of long cord had absent foetal heart beats, 5 were due to cord prolapse and 1 case was due to nuchal cord resulted in to high perinatal mortality i.e.6 (4.8\%)

CONCLUSION: In present study it was observed that cord length varies considerably, minimum being $28 \mathrm{~cm}$ and maximum $98 \mathrm{~cm}$. average cord length was 50-60 cm. There was no relation between maternal age, parity with umbilical cord length. Though the difference was not statistically significant, male foetuses have been found to have cords marginally longer than the female foetuses. Cord complications were found in long cord group only. Higher incidence of caesarean section was observed in long cord group. This may be due to cord complications and abnormalities in long cords, which may increase percentage of foetal distress. Perinatal mortality was high in long cord group.

\section{REFERENCES:}

1. Browne F.J.: Abnormalities of Umbilical Cord, which may cause antenatal death. J. of Obstet. \&Gyneacol. Of Brit Empire. 1925; 32: 17-48.

2. MalpasP.: Length of the human Umbilical Cord at term. Brit. Med. J. 1964; 1: 673-674. 
3. Walker C. W., Pye G. B.: The length of Umbilical Cord A statistical report. Brit. Med. J. 1960; 1 : 546-548.

4. Agboola A.: Correlates of human umbilical cord length. Int. J. Gynaecol. Obstet. 1978; 16: 238-239.

5. Soerrens T. \&Bekke T.: The length of human umbilical cord in vertex and breech presentation. Am. J. of Obstet. \&Gynaecol. 1986; 5: 154; 1086-87.

6. GulatiIndu\&Batra S.: Correlation of of Umbilical cord length wirth normal and abnormal presentation. J. of Obstet. \&Gynaecol. Of India. Nov. 1991; 430-32.

7. AdinmaJ.I.: The Umbilical cord : study of 1000 consecutive deliveries. Int. J. of Fertil. Menopausal Stud. 1993; 38: 175-9.

8. Rayburn W.F.: Umbilical cord length and intrapartumcomplications.Obstet. Gynaecol. 1981; 57: 450.

9. J. Mishra \& Vijayalaxmi: correlation of length of umbilical cord of the foetus with outcome of the labour. J. obstet. \&Gynaecol of India, 1987.

10. T. N. SinnaThuray: The nuchal cord incidence and significance. J. Obstet. \&Gynaecol. Brit. Cwlth. April 1966; 73, 226-231.

11. Shunji,yukiko fuse: Length of the Umbilical Cord and Perinatal outcomes in Japanese Singleton Pregnancies Delivered at Greater than or equal to 34 Weeks gestation J clin Gynecol obstet.2012;1(4-5):57-62

12. Begum A A, sultana $H$, hasan $R$,Ahemad M: a clinical study of fetal outcome In Cases of nuchal cord:JAFMC Bangladesh vol.7 No.1 june2011:25-27

13. Nilesh\&mangla shinde :study of length of umbilical cord and fetal outcome: a Study of 1000 deliveries:journal of obstetrics and gynaecology of india.vol.62 Issue 5.oct2012(520-525)

Table I: Distribution of cases in each group

\begin{tabular}{|l|l|l|}
\hline Group & Cord length in cm & No. of cases \\
\hline Short cord group & Less than $50 \mathrm{~cm}$ & 20 \\
\hline Long cord group & More than $60 \mathrm{~cm}$ & 80 \\
\hline Control & $50-60 \mathrm{~cm}$ & 100 \\
\hline
\end{tabular}

Table II: Range of cord length

\begin{tabular}{|l|l|l|}
\hline Umbilical cord length (cm) & Study & Controls \\
\hline $25-29$ & 1 & - \\
\hline $30-39$ & 3 & - \\
\hline $40-49$ & 16 & - \\
\hline $50-60$ & - & 100 \\
\hline $60-70$ & 67 & - \\
\hline $70-80$ & 5 & - \\
\hline $81-90$ & 5 & - \\
\hline 91 and above & 3 & - \\
\hline
\end{tabular}


Table III: Age distribution And Cord Length

\begin{tabular}{|l|l|l|l|}
\hline \multirow{2}{*}{ Age in years } & \multicolumn{2}{|l|}{ Study } & \multirow{2}{*}{ Control } \\
\cline { 2 - 3 } & Short cord & Long cord & \\
\hline $15-19$ & $2(10.1 \%)$ & $10(12.5 \%)$ & 12 \\
\hline $20-24$ & $10(50 \%)$ & $46(57.5 \%)$ & 52 \\
\hline $25-29$ & $7(35 \%)$ & $15(18.75 \%)$ & 24 \\
\hline $30-34$ & $1(5.1 \%)$ & $9(11.25 \%)$ & 12 \\
\hline
\end{tabular}

Table IV: association of Umbilical Cord Length With Parity

\begin{tabular}{|l|l|l|l|l|}
\hline \multirow{2}{*}{ Parity } & Study & Control \\
\cline { 2 - 5 } & $\begin{array}{l}\text { No. of } \\
\text { Cases }\end{array}$ & $\begin{array}{l}\text { Mean cord } \\
\text { length }\end{array}$ & $\begin{array}{l}\text { No. of } \\
\text { cases }\end{array}$ & $\begin{array}{l}\text { Mean cord } \\
\text { length }\end{array}$ \\
\hline Primipara & 50 & $60.54+\_12.42$ & 40 & $52.87+\_2.81$ \\
\hline Second para & 36 & $60.47+12.57$ & 34 & $54.17+\_2.64$ \\
\hline Third para & 11 & $62.72+\_12.93$ & 18 & $53.88+\_2.94$ \\
\hline Fourth para & 3 & $63+\_11.35$ & 8 & $52.97+\_3.60$ \\
\hline
\end{tabular}

Table V: Umbilical Cord Length And Sex of The New-born

\begin{tabular}{|c|c|c|c|c|c|c|}
\hline \multirow[t]{3}{*}{ Sex } & \multicolumn{4}{|c|}{ Study group } & \multicolumn{2}{|c|}{ Control group } \\
\hline & \multicolumn{2}{|c|}{ Short cord } & \multicolumn{2}{|c|}{ Long cord } & \multirow{2}{*}{$\begin{array}{l}\text { No. of } \\
\text { cases }\end{array}$} & \multirow{2}{*}{$\begin{array}{l}\text { Mean } \\
\text { umbilical cord } \\
\text { length }\end{array}$} \\
\hline & $\begin{array}{l}\text { No. of } \\
\text { cases }\end{array}$ & $\begin{array}{l}\text { Mean } \\
\text { umbilical } \\
\text { cord length }\end{array}$ & $\begin{array}{l}\text { No. of } \\
\text { cases }\end{array}$ & $\begin{array}{l}\text { Mean } \\
\text { umbilical } \\
\text { cord length }\end{array}$ & & \\
\hline Male & 12 & $40.08+2.94$ & 42 & $66.24+\_11.88$ & 62 & $53.69+2.92$ \\
\hline Female & 8 & $41.62+22.64$ & 38 & $65.69+\_12.11$ & 58 & $53.28+22.81$ \\
\hline
\end{tabular}

Table VI: Distribution of cases according to birth weight

\begin{tabular}{|l|l|l|l|}
\hline \multirow{2}{*}{ Weight in kg } & Groups \\
\cline { 2 - 4 } & Short cord $(\mathbf{n = 2 0})$ & Long cord $\mathbf{( n = 8 0 )}$ & Controls \\
\hline $2-2.4$ & 5 & 22 & 28 \\
\hline $2.5-2.9$ & 6 & 38 & 58 \\
\hline 3 and above & 9 & 20 & 14 \\
\hline
\end{tabular}

Table VII: Distribution Of Cases According to Foetal Distress

\begin{tabular}{|l|l|l|}
\hline & \multicolumn{2}{|l|}{ Study group } \\
\cline { 2 - 3 } & Short cord & Long cord \\
\hline Foetal distress present & $\mathbf{1}(\mathbf{5 \% )}$ & $25(31.25 \%)$ \\
\hline No foetal distress & $\mathbf{1 9 ( 9 5 \% )}$ & $49(61.25 \%)$ \\
\hline
\end{tabular}




\section{ORIGINAL ARTICLE}

Table VIII: Umbilical Cord Length And Cord ComplicationsAnd Mode Of Delivery

\begin{tabular}{|c|c|c|c|c|c|}
\hline \multirow[t]{3}{*}{ Complications } & \multicolumn{4}{|c|}{ Study group } & \multirow[t]{3}{*}{ Control } \\
\hline & \multirow{2}{*}{$\begin{array}{l}\text { Short } \\
\text { cord }\end{array}$} & \multicolumn{3}{|l|}{ Long cord } & \\
\hline & & No. & \multirow[b]{2}{*}{ Vaginal } & \multirow[b]{2}{*}{ LSCS } & \\
\hline No. of cases & 20 & 80 & & & 100 \\
\hline Cord entanglement & - & $71(88.75 \%)$ & $43(53.8 \%)$ & 28 & - \\
\hline True knot & - & $2(2.5 \%)$ & 2 & - & - \\
\hline Cord compression & - & $2(2.5 \%)$ & - & 2 & - \\
\hline Cord prolapse & - & $5(6.25 \%)$ & 5 & - & - \\
\hline
\end{tabular}

Table IX: Distribution of Cases According To APGAR Score

\begin{tabular}{|c|c|c|c|c|c|c|c|c|c|c|}
\hline \multirow{3}{*}{$\begin{array}{l}\text { APGAR } \\
\text { score }\end{array}$} & \multicolumn{5}{|c|}{ Long cord } & \multicolumn{5}{|c|}{ Short cord } \\
\hline & \multicolumn{2}{|c|}{ Vaginal } & \multicolumn{2}{|l|}{ LSCS } & \multirow{2}{*}{$\begin{array}{l}\text { Perinatal } \\
\text { deaths }\end{array}$} & \multicolumn{2}{|c|}{ Vaginal } & \multicolumn{2}{|l|}{ LSCS } & \multirow{2}{*}{$\begin{array}{l}\text { Perinatal } \\
\text { deaths }\end{array}$} \\
\hline & $1 \mathrm{~min}$ & $5 \mathrm{~min}$ & $1 \mathrm{~min}$ & $5 \mathrm{~min}$ & & $1 \mathrm{~min}$ & $5 \mathrm{~min}$ & $1 \mathrm{~min}$ & $5 \mathrm{~min}$ & \\
\hline $1-4$ & 9 & 2 & 3 & 1 & $6^{*}$ & 1 & - & - & - & - \\
\hline $5-7$ & 3 & - & 1 & - & - & 3 & 1 & - & - & - \\
\hline $8-10$ & 34 & 44 & 24 & 27 & - & 16 & 19 & - & - & - \\
\hline
\end{tabular}

